\title{
Furuncle Persistent to Long-Term Antibiotic Therapy in a Non-Tropical Region: A diagnosis that must not be overlooked: Furuncular cutaneous myiasis
}

\author{
Tropikal Olmayan Bölgelerde Uzun Süre Antibiyotik Tedavisine Cevap Vermeyen Fronkül: \\ Gözden Kaçırılmaması Gereken Bir Tanı; Fronküler Kutanöz Miyazis
}

\section{Hatice Uce Özkol, Ömer Çalka}

Department of Dermatology, Yüzüncü Yıl University, Faculty of Medicine, Van, Turkey

\begin{abstract}
We present the case of a 12-year-old boy with furuncular myiasis living in an area with continental climate. The boy was admitted to our clinic with a wound on his nape, which started as a little acne and progressed to a large wound in which pus flowed continuously. He complained of itching and was treated with penicillin, clarithromycin, terbinafine, and ibuprofen in the last 2 months, with no big success. Otherwise, the patient was healthy, and his hygienic conditions were within normal standards. The dermatologic examination revealed an off-white ulcer measuring approximately $1 \times 2 \mathrm{~cm}$ in the occipital region with regular contours, elevated borders, and purulent flow, while the skin surrounding the ulcer was normal. In the course of the examination, a living larva was removed using a forceps. The ulcer and the surroundings were washed with polyvinylprolidone iodine solution, while fusidic acid pomade was topically applied. The ulcer regressed significantly after 15 days of treatment.
\end{abstract}

(Turkiye Parazitol Derg 2014; 38: 138-40)

Key Words: Furuncular myiasis, continental climate

Received: 16.07.2013

Accepted: 20.10 .2013

\section{ÖZET}

Bu makalede karasal iklimde yaşayan 12 yaşında bir erkek çocuğunda fronküler miyazis sunuyoruz. Polikliniğimize ensesinde küçük bir sivilce şeklinde başlayıp gittikçe büyüyen ve içinden irin akan yarası olan bir erkek çocuğu başvurdu. Çocuk kaşıntıdan ve yaklaşık iki ay süren penisilin, claritromisin, terbinafine ve ibuprufen tedavilerine rağmen tedavi olamamaktan şikâyetçiydi. Hastanın hijyen koşulları normal standartlardaydı ve sağlıklı bir bireydi. Dermatolojik muayenede oksipital bölgede yerleşen yaklaşık 1×2 cm ebatlı, sınırları düzenli, kenarları kalkık ve pürülan akıntının olduğu ülser mevcuttu. Ülserin etrafındaki deri normal görünümdeydi. Muayene sırasında görülen canlı larva forseps yardımıyla çıkarıldı. Ülser ve çevresi Betadin polivinilprolidon iyot solüsyon ile yıkandı ve fucidic acit merhem topikal olarak tedaviye eklendi. Ülser on beş günlük tedavi sonrasında belirgin olarak geriledi.

(Turkiye Parazitol Derg 2014; 38: 138-40)

Anahtar Sözcükler: Fronküler miyazis, karasal iklim

Geliş Tarihi: 16.07.2013

Kabul Tarihi: 20.10.2013

Address for Correspondence / Yazışma Adresi: Dr. Hatice Uce Özkol, Department of Dermatology, Yüzüncü Yıl University, Faculty of Medicine, Van, Turkey Phone: +90 4322150473 E-mail: drhaticeuce@gmail.com DOI:10.5152/tpd.2014.3288

CCopyright 2014 Turkish Society for Parasitology - Available online at www.tparazitolderg.org

OTelif hakkı 2014 Türkiye Parazitoloji Derneği - Makale metnine www.tparazitolderg.org web sayfasından ulaşılabilir. 


\section{INTRODUCTION}

Some fly species lay their eggs on intact or damaged tissues of humans. Myiasis develops as a result of conversion of these eggs into larva. The leading factor in the occurrence of the disease is a lack of hygiene. Furuncular myiasis rarely develops on intact skin-mostly on neglected leg ulcers, various wounds, and tumors (1). The main fly species that cause such symptoms are Dermatobia hominis and Cordylobia anthropophaga. Mechanical removal of larvae is sufficient for treatment (2). In this paper, myiasis that developed on intact skin is presented.

\section{CASE REPORT}

A 12-year-old boy was admitted to our clinic with a wound on his nape. It started as a little acne and progressed to a large wound in which pus flowed continuously. He sometimes had the completed from itching. He used drugs, such as penicillin, clarithromycin, terbinafine, and ibuprofen within the previous 2 months; however, his wound did not heal. Otherwise, the patient did not have any health problems. His life and hygiene conditions were within normal standards. Dermatologic examination revealed an off-white ulcer measuring approximately $1 \times 2 \mathrm{~cm}$ in the occipital region with regular contours, elevated borders, and purulent flow, while the skin surrounding the ulcer was normal. In the course of the examination, motility was observed within the ulcer, and the living organism was removed using a forceps (Figure1). The ulcer and surroundings were washed with polyvinylprolidone iodine solution, and fusidic acid pomade was topically applied. The ulcer regressed significantly after 15 days of treatment.

\section{DISCUSSION}

Myiasis is usually caused by the larvae of the Calliphoridae, Sarcophagidae and Oestridae families belonging to Diptera. These larvae infest various human tissues, such as skin, eye, ear, anus, vagina, and urethra (3). Cutaneous myiasis usually occurs in cases in which the skin integrity is interrupted. These include cutaneous malignancies, foot ulcers, chronic wounds, and poor hygiene (4). Myiasis is more frequent in the tropical and subtropical zones of America and Africa, as flies can reproduce more in hot and humid climates. It is rare in Europe and North America (5). Our patient was living in the city of Van (a city in eastern Anatolia), which is located in an area with a terrestrial climate.

Worldwide, the most common fly species leading to infestations in humans are Dermatobia hominis, which is native to the Americas and Cordylobia anthropophaga, which is common in East and Central Africa. The contamination route of larvae varies depending on the fly species. For example, Dermatobia hominis deposits its eggs on mosquitoes, and the larvae hatch and penetrate the skin while the mosquito is biting a human. Cordylobia anthropophaga leaves its eggs on damp clothes, dirty coverings, and sand. These larvae may live without feeding for 15 days. Therefore, clothes left outside should be worn after ironing (6). Our patient had a history of mosquito bite; however, the larva was not identified, and therefore, it is also not possible to.

Cutaneous myiasis has three clinical types: furuncular, migratory cutaneous, and wound myiasis. Furuncular myiasis is known to

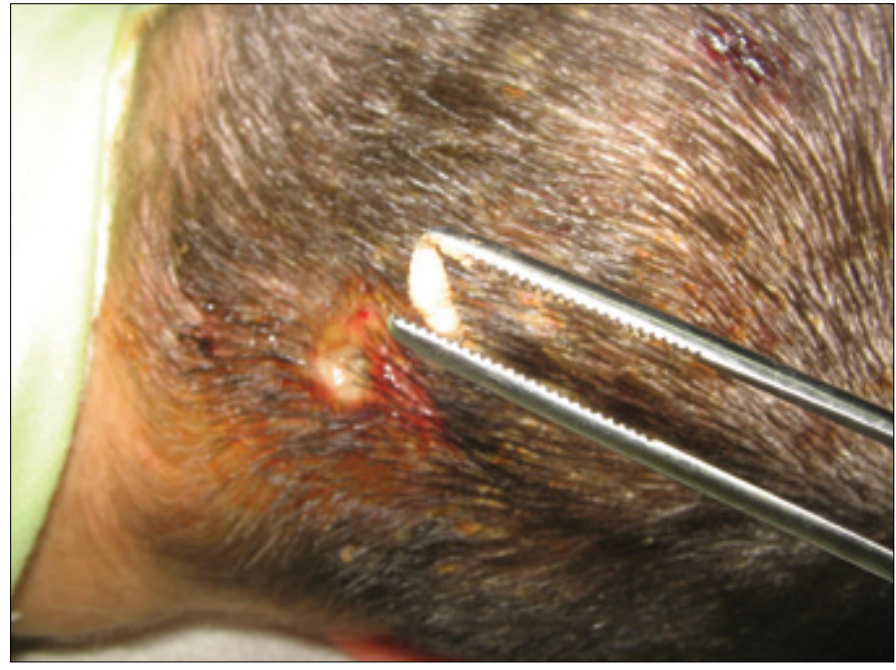

Figure 1. Image of purulent ulcer and living larva

be observed on intact skin. Cordylobia anthropophaga most commonly leads to furuncular lesions on the hip, thigh, and trunk, whereas D. hominis gives rise to lesions on the scalp, arms, legs, and face (3). The differential diagnosis of furuncular myiasis includes ruptured epidermoid cyst, abscess, furuncle, and foreign body reaction. Migratory cutaneous myiasis develops in individuals caring for cats and horses. There is usually a clinical condition similar to larva migrans. The most common etiologic agents are Hypoderma bovis and Gasterophilus intestinalis (6). Wound myiasis develops as a result of leaving fly eggs or larvae deposited on neglected or open wounds. Wounds are usually malodorous and purulent, and flies are easily attracted. Chrysomya bezziana, Lucilia sericata, and Cochliomyia hominivorax are the most commonly detected species in wound myiasis (7).

Apart from our study, we encountered only one case of furuncular myiasis in a child that resulted from Wohlfahrtia magnifica infestation in the literature of Turkey (8), whereas there are a few studies about general myiasis, such as aural myiasis caused by Wohlfahrtia magnifica (9-11), naso-ophthalmic myiasis caused by Oestrus ovis and Lucilia spp $(12,13)$, urogenital myiasis caused by Psychoda albipennis (14), nosocomial oral myiasis caused by Sarcophaga sp (15), wound myiasis caused by Wohlfahrtia magnifica $(16,17)$, subungual myiasis caused by Calliphora spp (18), and intracerebral myiasis caused by Hypoderma bovis (19). As we mentioned above, aural, ophthalmic, and wound myiasis are the most commonly seen types of myiasis reported in Turkey. The frequently informed species was Wohlfahrtia magnifica.

Removal of the larva is usually enough for treatment of furuncular myiasis; however, the larvae should be removed without damaging them. In cases when larval body parts are left inside the wound, it may lead to foreign body reactions (20). If the punctum in the center of the lesion is not fully opened, blockage is performed with liquid paraffin, nail polish, wax, or petrolatum gel. Later, the larva is removed using a forceps when it moves up for breathing. After removal of the larva, antiseptic coverings or antibiotics are used in case of secondary infections (21). In wound myiasis, larvae are removed with irrigation, debridement, or surgical methods. Oral ivermectin therapy may be preferred as an alternative treatment, particularly in ocular and oral 
involvement. The lesion in our case was as an ulcer in which larva was easily observed. The larva was removed through a forceps, and the lesion was washed with polyvinylprolidone iodine. Topical antibiotic treatment was started to avoid a secondary infection. However, the larva was not identified, and therefore we are not able to say to which fly species it belonged.

\section{CONCLUSION}

We present the case of furuncular myiasis in a 12-year-old boy living in an area with a continental climate. Furuncular myiasis is very rarely seen in the continental climate.

Hasta Onamı: Çalışmamızın retrospektif tasarımından dolayı etik komite onayı alınmamıştır.

Hakem Değerlendirmesi: Dış bağımsız.

Yazar Katkıları: Fikir - H.U.Ö.; Tasarım - H.U.Ö.; Denetleme H.U.Ö., Ö.Ç.; Kaynaklar - H.U.Ö.; Malzemeler - H.U.Ö; Veri toplanması ve/veya işlemesi - H.U.Ö.; Analiz ve/veya yorum H.U.Ö., Ö.Ç.; Literatür taraması - H.U.Ö., Ö.Ç; Yazıyı yazan H.U.Ö.; Eleştirel İnceleme - H.U.Ö., Ö.Ç; Diğer - H.U.Ö., Ö.Ç.

Çıkar Çatışması: Yazarlar çıkar çatışması bildirmemiştir.

Finansal Destek: Yazarlar bu çalışma için finansal destek almadıklarını beyan etmiştir.

Informed Consent: Ethics committee approval was not received due to the retrospective nature of this study.

Peer-review: Externally peer-reviewed.

Author Contributions: Concept - H.U.Ö.; Design - H.U.Ö.; Supervision - H.U.Ö., Ö.Ç.; Funding - H.U.Ö.; Materials - H.U.Ö.; Data Collection and/or Processing - H.U.Ö.; Analysis and/or Interpretation - H.U.Ö., Ö.Ç.; Literature Review - H.U.Ö., Ö.Ç.; Writing - H.U.Ö.; Critical Review - H.U.Ö., Ö.Ç.; Other - H.U.Ö., Ö.ç.

Conflict of Interest: No conflict of interest was declared by the authors.

Financial Disclosure: The authors declared that this study has received no financial support.

\section{REFERENCES}

1. Mathieu ME, Wilson BB. Myiasis. In Principles and practice of infectious diseases. Eds Mandell LG, Bennett JE, Dolin R. 6th ed. Philadelphia: Churchill- Livingstone 2005: 3307-10.

2. Boggild AK, Keystone JS, and Kain KC. Furuncular Myiasis: A Simple and Rapid Method for extraction of Intact Dermatobia hominis Larvae. CID 2002; 35: 336-8. [CrossRef]
3. Hall M, Wall R. Myiasis of humans and domestic animals. Adv Parasitol 1955; 35: 257-334. [CrossRef]

4. Parlak AH. Deri Kurtlanması. Dermatoloji. Editörler: Tüzün Y, Gürer MA, Serdaroğlu S, Oğuz O, Aksungur VL. Nobel Tıp Kitapevleri 3. Baskı 2008; 710-1.

5. Millikan LE. Myiasis. Clin Dermatol 1999; 17: 191-5. [CrossRef]

6. Lupi O. Cutanoeus Myiasis. In: Dermatology. Eds:Callen PJ, Horn TD, Mancini AJ, Salasche SJ, Schaffer JV, Schwarz T, Stingle G, Stone MS. Second edition, 2008, Mosby -Elsevier, 1300-2.

7. Sesterhenn AM, Pfützner W, Braulke DM, Wiegand S, Werner JA, Taubert A. Cutaneous manifestation of myiasis in malignant wounds of the head and neck. Eur J Dermatol 2009; 19: 64-8.

8. Tuygun N, Taylan-Ozkan A, Tanir G, Mumcuoğlu KY. Furuncular myiasis in a child caused by Wohlfahrtia magnifica (Diptera: Sarcophagidae) associated with eosinophilia. Turk J Pediatr 2009; 51: 279-81.

9. Yuca K, Caksen H, Sakin YF, Yuca SA, Kiriş M, Yilmaz H, et al. Aural myiasis in children and literature review. Tohoku J Exp Med 2005; 206: 125-30. [CrossRef]

10. Bayindir T, Miman O, Miman MC, Atambay M, Saki CE. Bilateral aural myiasis (Wohlfahrtia magnifica): a case with chronic suppurative otitis media. Turkiye Parazitol Derg 2010; 34: 65-7.

11. Yildirim I, Ceyhan M, Cengiz AB, Saki CE, Ozer E, Beken S, Cilsal E. What's eating you? Cutaneous myiasis (Wohlfahrtia magnifica). Cutis 2008; 82: 396-8.

12. Eyigör H, Dost T, Dayanir V, Başak S, Eren H. A case of naso-ophthalmic myiasis. Kulak Burun Bogaz Ihtis Derg 2008; 18: 371-3.

13. Cetinkaya M, Ozkan H, Köksal N, Coşkun SZ, Hacimustafaoğlu M, Girişgin O. Neonatal myiasis: a case report. Turk J Pediatr 2008; 50: 581-4.

14. Güven E, Kar S, Doğan N, Karaer Z. Urogenital myiasis caused by Psychoda albipennis in a woman. Turkiye Parazitol Derg 2008; 32: 174-6.

15. Yazar S, Dik B, Yalçın S, Demirtaş F, Yaman O, Öztürk $M$, Şahin i. Nosocomial Oral Myiasis by Sarcophaga sp. in Turkey. Yonsei Med J 2005; 46: 431-4. [CrossRef]

16. Bayindir T, Cicek MT, Atambay M, Kizilay A. Cutaneous myiasis in a malignant wound of the head and neck region. J Craniofac Surg 2012; 23: 19-20. [CrossRef]

17. Uzun L, Cinar F, Beder LB, Aslan T, Altintas K. Radical mastoidectomy cavity myiasis caused by Wohlfahrtia magnifica. J Laryngol Otol 2004; 118: 54-6. [CrossRef]

18. Balcioğlu IC, Ecemiş $T$, Ayer A, Ozbel Y. Subungual myiasis in a woman with psychiatric disturbance. Parasitol Int 2008; 57: 509-11. [CrossRef]

19. Kalelioğlu M, Aktürk G, Aktürk F, Komsuoğlu SS, Kuzeyli K, Tiğin Y, et al. Intracerebral myiasis from Hypoderma bovis larva in a child. Case report. J Neurosurg 1989; 71: 929-31. [CrossRef]

20. Deng Y, Liu F, Chen X, Lu S. The first imported cutaneous myiasis due to Cordylobia anthropophaga in China. Int J Dermatol 2013; 52: 120-2 [CrossRef].

21. Dias E, Dias M. Cutaneous myiasis. Indian Pediatr 2011; 48: 907. [CrossRef] 